\title{
Inventory and Symbolic Meaning of Traditional Ceremonies Related to the Mythology of Queen Kalinyamat in North Jepara
}

\author{
Laura Andri R.M.,S.S.,M.A.* Rahma Wulan S. \\ Departement of Indonesian Literature, Faculty of Humanities, Diponegoro University
}

\begin{abstract}
The mythology of Queen Kalinyamat is very popular in the North Jepara area, especially Keling District, Donorojo District, Kembang District, Bangsri District, and Mlonggo District. Ratu Kalinyamat is known by the public as a legendary figure, because it is considered powerful, brave, patient, clever, loyal and has a defending spirit. Traditional ceremonies related to the mythology of the Queen Kalinyamat that developed in the Jepara region are quite a lot, for example the tradition of Tulemba Tulakan in Keling District. The focus of this research study relates to the inventory of traditional ceremonies with the same source, namely the mythology of Queen Kalinyamat. In addition, the symbolic meaning will be explored behind the traditional ceremony that has been inventoried. This is done as an initial step in the effort to preserve regional culture. The research implementation is carried out by applying qualitative research methods, through observation, interview, and documentation techniques. The collected data were analyzed using the comparative descriptive method.
\end{abstract}

Keyword: Mythology, Queen Kalinyamat, traditional ceremony, inventory, symbolic meaning

\section{Introduction}

Traditional ceremony is one of the rituals performed by the community. In each region, traditional ceremonial ceremonies have their own unique characteristics, ranging from the mention or naming of different rituals, to the process that has different procedures. The function of traditional ceremonies in general leads to the function of the values of belief or religion, which is to ask the Almighty God to be blessed with abundant blessings and to avoid catastrophe.

A community group, in living life, always adhere to socio-cultural beliefs. This belief then forms a custom and cultural building which is then reflected in the ritual or ceremonial process in society, which describes the true character of the belief itself. This trust is carried out to establish positive relationships with spirits, both feared and respected spirits. Ceremonies in society are very prerequisite with ritualistic values, solemnity and reverence.

\footnotetext{
${ }^{*}$ Corresponding author : lauraandrirm01@gmail.com
} 
In addition, most of the traditional ceremonial rites are expressions of inferiority in the presence of the forces of nature, because they believe that community activities intersect directly with the forces behind human nature [1].

The Queen Kalinyamat figure is very popular in the Jepara region, especially in the northern part of Jepara, namely Keling District, Donorojo District, Kembang District, Bangsri District, and Mlonggo District. Traditional ceremonies related to the mythology of the Queen Kalinyamat that developed in the Jepara region are quite a lot, for example the tradition of Tulemba Tulakan in Keling District.

The people of Jepara in the north carry out the appreciation of tradition and culture related to the Queen Kalinyamat figure in synergy with the existing diversity. This can be seen from the lively traditional ceremonies that are held every year. Although some people gradually began to shift towards realistic thinking, but most people still hold fast to the beliefs about Ratu Kalinyamat's Mythology.

\section{Research Methods}

Research on traditional ceremonies is research that uses a qualitative approach. Data collection techniques are focused on:

a. Observation is a direct observation of an object to be examined. Watching the research object directly is one step to find out and get more accurate and factual data.

b. Interview is a way to collect data by asking questions directly to informants or authorities (an expert or authorized in a problem).

c. Literature study is a study conducted by digging information and data from written sources about the object to be examined so that sources of information are found that are directly or indirectly related to the research topic.

d. Documentation becomes one of the supporting factors during the research and writing process, because with the existing documentation the researcher can re-examine the research object in more detail, and the documentation can also be used as authentic evidence for accountability in this writing.

This research belongs to the category of field research. This research base is sociological that moves according to qualitative research. The technique used to analyze research data is a qualitative descriptive analysis technique with the steps: (a) Choosing relevant data, (b) Making objective notes, in this case at the same time carrying out classification and editing (reducing), (c) Making reflective notes, (d) Summing up data, and (e) Conducting triangulation that is checking the truth of the data by summarizing duplicate data obtained in three ways: (1) extend the time of observation in the field with the aim to match the data that has been written with field data, (2) match the data that has been written by asking back to the informant, and (3) match the data that has been written with the source of the library.

\section{Literature Review}

Traditional ceremonies can be interpreted as a ritual of giving offerings to the ruler, the Almighty God, as a form of thanksgiving and requests for salvation. This traditional ceremony is carried out by all members of the community. The mythology of Queen Kalinyamat is central to the emergence of traditional ceremonies in the North Jepara region.

Vella Fitriana (2010) in her thesis entitled "Hermitage of the Queen Kalinyamat Hermitage in Tulakan Village Keling Subdistrict, Jepara Regency, Central Java Province (An Folklore Fist)" analyzes the comparison of Queen Kalinyamat hermitage folklore, analysis of folklore folklore, the form of austerity folklore Ratu Kalinyamat, the myths contained in Ratu Kalinyamat's hermitage folklore, the function of Ratu Kalinyamat's hermitage folklore, 
and the tradition of manganan and jembul ceremonies in Ratu Kaliyamat's hermitage folklore $[2]$.

Rukiyah (2019), in his article titled "The Symbolic Meaning of Jembul Tulakan Ritual, Donorojo District, Jepara Regency" [3]. The purpose of the research is to explain the origin of the Jembul Tulakan Ritual, its ritual procession, and its symbolic meaning. The method used in this research is interview, literature study, direct analysis, and descriptive presentation. Theories used as the basis of research are folklore theory and cultural theory. The results obtained are the Jembul Tulakan Ritual starting with the dream of eight villagers at the same time, the ritual procession begins with washing the feet of the village head, circling the jembul, and resikan. The symbolic meaning of this ritual includes a sense of togetherness and brotherhood.

Laura Andri RM (2019), in her research entitled "The Meaning and Function of the Sea Alms Ceremony for the Banyutowo Dukuhseti Pati Community" [4]. Sea alms ceremony is a ritual activity that is carried out once a year by the Banyutowo village community, Dukuhseti district, Pati Regency precisely in the month of Sura (Javanese calendar). This tradition has been going on for a long time and is able to become a cultural attraction that is firmly attached to the Banyutowo community. In general, the ceremony has the aim to express gratitude for the fortune given by God Almighty and ask for safety for the fishermen and their families so that in carrying out their daily duties do not get any interference. The focus of this study is about the meaning contained in the sea alms ceremony and its function for the surrounding community.

This research will be different from previous studies. This research is broader and emphasizes the collection/inventory of traditional ceremonies that arise because of the similarities of mythology, the procession of the ceremony and the meaning and function contained in the traditional rituals.

\section{Discussion}

\subsection{The tradition of the Tulakan Jembul Ceremony}

The tradition of the Jembul ceremony is an activity carried out by the people of Tulakan Village, Keling District, Jepara Regency, Central Java Province. Hereditary is carried out with the intention of preserving ancestral cultural heritage. This ceremony is a tradition that has magical and sacred value, aiming to convey prayer requests so that the Tulakan people are given abundant safety, health, fortune.

a. Mangani, on Friday night Wage, because according to the history that says that the arrival of Queen Kalinyamat to be imprisoned is Friday Wage most of the population of Tulakan Village who are quite numerous bring rice, ingkung chicken along with side dishes in the form of tofu, tempeh along with stir-fried beans and noodles. The program continued with the welcoming ceremony by the head of Tulakan Village, giving thanks to God for the grace and safety given to the people of Tulakan Village, then continued with the slametan which was an affirmation and reinforcement of the general cultural order of his power to eliminate the supernatural forces that disorderly, joint prayer or tahlil led by religious leaders or people who are religious experts in the village of Tulakan, the aim is to pray for Queen Kalinyamat so that her spirit is peaceful and forgiven of the sins that have been committed while living in the world. The memorial event was finished, the people then fought over the ritual flower because the Tulakan villagers believed they would get a blessing if they got the ritual flower.

b. The highlight of the Jembul Ceremony. Javanese generally call it Jambul, meaning that part of the head's hair is intentionally styled so that it rises slightly upwards. The Jembul 
in the procession is a series of offerings placed in a ancak, a kind of basket or box made of wood measuring about 1 x 2 meters. At the bottom tied with two bamboo lined stems that serve to carry. Jembul consists of jembul lanang which contains a variety of foods, such as jadah, jenang, tape, and jadul wadon, which contains ambengan rice and side dishes. Each Jembul at the top there are wooden puppet dolls, these puppet dolls symbolize the people who are guarding Queen Kalinyamat when conducting austerities.

Jembul is a symbol of the expression uttered by Queen Kalinyamat while undergoing austerity that is "Ingsun ora pisan-pisan saka tapa ingsun, yen durung bisa keramas getihe lan kesed jambule Arya Penangsang," meaning: "I will not move from my hermitage, while not shampooing with blood and wash feet with Arya-stimulant hair". The traditional Jembul ceremony took place at the Pendapa office of the Head of Tulakan Village, Keling District, Jepara Regency. When the traditional ceremony of Jembul is held once a year, which is once a year, every month Apit, Monday Pahing, which is held at noon.

c. The program around Jembul three times is the core of the Jembul Tulakan process. Around Jembul activities are carried out by top brass followed by ledhek or tayup dancers and village leaders. This symbol means that the senior wife must always accompany and be able to keep up with her husband, as long as he leads the village. The procession was carried out to re-describe the atmosphere of Queen Kalinyamat who was always loyal to her husband. Ledhek or tayub dancers are described as wives who must always be faithful to accompany their husband. The four Jembul-Jembul symbol was intended to represent the dukuhs at that time and to face the Nayaka Praja to deliver the upriver to the Queen Kalinyamat. The loyalty of the Nayaka Praja was shown when the queen did her retreat. This atmosphere is more interpreted as a reminder that Tulakan village leaders always take the time to pay attention to the staff of their village apparatus in carrying out daily tasks. This monitoring will create a safe village situation.

d. Equipment for carrying out the Jembul ceremony is as follows:

1) Kemenyan, the meaning of giving to the people of Tulakan Village is to respect the jinn so as not to disturb the ceremonial tradition. In addition, the fragrant smell is a symbol of the honest sense of smell, if you smell a fragrance it will be said to be fragrant and vice versa if you smell a foul odor it will be said to be foul.

2) Kembang Setaman, is a symbol of human breath, because all that is in front of humans is a teacher for his life journey.

3) Tumpeng rice, symbolizes a hope to God Almighty so that the request and what has been desired can be achieved or granted.

4) Panggang, for the people of Tulakan Village to apologize to all members of the community to the Prophet Muhammad to obtain his intercession later.

5) Lauk, which is a complement to the main food, then in life as a symbol of being a connoisseur one of them is a family, for the people of Tulakan Village is as a complement in life.

6) Jadah, for the people of Tulakan Village is a symbol of purity and truth, to keep away from natural disturbances.

7) Ancak, for the people of Tulakan Village is to describe the situation of Tulakan Village as a place to live for people who have a variety of characters, and in Tulakan Village it has a diverse natural wealth.

8) Ambengan rice, for the people of Tulakan Village is a symbol of togetherness and harmony between residents.

9) Gorengan, for the people of Tulakan Village is as an encouragement in life.

10) Tape for the people of Tulakan Village is without 'no calculation', meaning that in social life help one another without expecting anything in return.

11)Jenang for the people of Tulakan Village is that the Godha Sengkala can be distorted "away from temptations that are not good". 
The Purpose of Organizing the Tradition of the Jembul Ceremony Once a year, every month Apit on Monday Pahing, as a sign of gratitude to God Almighty for the blessings bestowed upon the residents of Tulakan Village. The community held a thanksgiving ceremony that was hereditary then known as almsgiving of the earth. As a step to remember the ascetic practices committed by Nyai Ratu Kalinyamat in demanding justice for the death of her husband Sultan Hadirin, who was killed by Arya Panangsang.

Benefits that can be taken from the tradition of Jembul ceremony in terms of cultural attractions, Jembul Tulakan traditional ceremony is quite interesting because it involves all the people who feel they have the tradition. By involving the community evenly, this tradition can be maintained from time to time with a variety of new nuances while maintaining the ceremonial requirements that are deemed necessary, both in terms of equipment and steps that must be passed. Every time the celebration will bring snacks and souvenir stalls and souvenirs that become typical food there. This attraction is able to bring a new form of economic activity as a business unit that supports tourism activities even though it is still in a small or local scope. The strategic steps taken by the Jepara Tourism Office can also be used as an indicator that the Tulakan Jembul Ceremony contributes to the attractiveness of tourists, by including it as one of the tour package schedules that can be visited.

\subsection{Ziarah Tradition}

The Javanese regional culture pattern that has been rooted in the souls of each of its supporters and passed down from generation to generation is known as a regional tradition. Regional traditions in Tulakan Village are pilgrimage traditions to places that are considered sacred. People are usually difficult to break away from their ancestors because the ties with their predecessors are tightly established, this is evident in the existence of traditions in the community that visit the places of their ancestors.

The ziarah habit at the place of the sacred figures is still widely practiced by the people of Tulakan Village and its surroundings, namely performing the pilgrimage tradition of Ratu Kalinyamat. They have an opinion that the spirits will come down to earth where the spirit in question is the spirit of the queen Kalinyamat, so that it will grant all requests. Beliefs of Tulakan Village, Keling Subdistrict, Jepara Regency, will play the role of Ratu Kalinyamat as a figure who has supernatural powers and has a noble, loyal, just and wise character so that after she dies she is considered to be a gatekeeper or in Javanese belief called dhanyang. The procedures for going on ziarah to Ratu Kalinyamat's visit are as follows:

a. Pilgrims first bring flowers for the purpose of pilgrimage.

b. Register yourself or fill out a guest book with the guards, with a little money to give sincerely to the funds for the maintenance of petilasan

c. Then head to the river Gajahan which is located near the petilasan for purposes, washing, bathing, performing ablution or just washing your face.

d. Then enter the pendapa and face the caretaker, hand over the flower then ask permission to enter the tomb or ask for a caretaker.

e. Once inside the tomb, it's up to what becomes his intentions and desires. Then ask God Almighty for help to be given ease and fluency in trying and get halal sustenance and blessings. Because most pilgrims are traders so that their trade is smooth.

f. After leaving the tomb, you can go home directly or bring water from the Gajahan river for healing and beauty for women. 


\subsection{Baratan Tradition}

The word baratan comes from the Arabic baraah or blessing which means safety and blessing. The Baratan party is held periodically once a year, which is on the 15 th of the month of Syakban. The purpose of this ceremony is to remember Queen Kalinyamat when bringing her husband's body, namely Sunan Hadirin who was killed by Aryo Penangsang. The peak event of the Baratan Party was held after the Isyak prayer.

Implementation of the Baratan Party Procession begins with evening prayers followed by reciting surah Yasin three times with the aim that God gives long life, abundant fortune, and remains in a state of Islamic faith until the end of life, then reads nisfu syakban prayers. After praying Isha and eating rice puli (puli derived from Arabic afwu lii, which means forgive me) who were given coconut that was burned or not burned, the people of Kriyan, Margoyoso, Purwogondo, and Robayan gathered at Al Makmur Mosque in Kriyan Village for the next doing a parade / carnival. The procession starts from Al Makmur Mosque and ends in Kalinyamatan District. Therefore, the community is enthusiastic in following the procession of the Baratan tradition because by attending the event they meet, greet, and forgive each other.

Ritual Objects and Equipment Ritual objects are considered to be a very important element in a ritual ceremony. The objects and tools used in the Baratan Party are as follows: a. Alquran/Surah Yasin Books

b. Lanterns/Torch as a symbol of enlightenment or illumination of life;

c. Puli rice as a symbol of mutual forgiveness.

\section{Conclusion}

This research focuses on the symbolic meanings that can be found in traditional ceremonies relating to Ratu Kalinyamat. In the study found three ceremonies that took place. First, it is the tradition of the Tulakan ceremony. Second, is the tradition of pilgrimage. While the third, is the tradition of the Baratan. All three ceremonies require a series of fairly complex processions and tools and items (offerings) that are very important for the procession to take place. Although the procession and equipment used are different, the three ceremonies have one common goal, namely as a medium to express gratitude to God Almighty, as well as a form of respect for Queen Kalinyamat. 


\section{Reference}

1. A. Ismail, Agama Nelayan Pergumulan Islam dengan Budaya Lokal, Yogyakarta : Pustaka Pelajar (2012)

2. V. Fitriana, "Cerita Rakyat Pertapaan Ratu Kalinyamat di Desa Tulakan Kecamatan Keling Kabupaten Jepara, Propinsi Jawa Tengah (Sebuah Tinjuan Folklor)" Skripsi S1 Fakultas Bahasa dan Seni Rupa, Universitas Sebelas Maret, Solo (2010)

3. Rukiyah. "Makna Simbolik Ritual Jembul Tulakan Kecamatan Donorojo Kabupaten Jepara" Anuva (Jurnal Kajian Budaya, Perpustakaan dan Informasi), Semarang : FIB Undip (2019)

4. Martini, L. Andri Retno, "Makna dan Fungsi Upacara Sedekah Laut bagi Masyarakat Banyutowo Dukuhseti Pati” Laporan Penelitian Fakultas Ilmu Budaya Undip, Semarang (2019)

5. Koentjaraningrat, Metode-Metode Penelitian Masyarakat, Jakarta : PT. Gramedia Pustaka Utama (1992)

6. _ Kebudayaan Jawa, Jakarta : Balai Pustaka (1994)

7. Purwadi. Upacara Tradisional Jawa Menggali Untaian Kearifan Lokal. Yogyakarta : Pustaka Pelajar (2005) 